\title{
Erratum: Mediating Retinal Ganglion Cell Spike Rates Using High-Frequency Electrical Stimulation
}

\section{OPEN ACCESS \\ Approved by: \\ Frontiers Editorial Office \\ Frontiers Media SA, Switzerland \\ *Correspondence: \\ Frontiers Production Office production.office@frontiersin.org \\ Specialty section: This article was submitted to \\ Neuroprosthetics, \\ a section of the journal \\ Frontiers in Neuroscience}

Received: 16 August 2019 Accepted: 16 August 2019

Published: 28 August 2019

Citation:

Frontiers Production Office (2019)

Erratum: Mediating Retinal Ganglion

Cell Spike Rates Using

High-Frequency Electrical Stimulation.

Front. Neurosci. 13:910.

doi: 10.3389/fnins.2019.00910

\section{Frontiers Production Office*}

Frontiers Media SA, Lausanne, Switzerland

Keywords: neuromodulation, retinal ganglion cell, high-frequency electrical stimulation, retinal implant, computational modeling, in vitro patch-clamp

\section{An Erratum on}

Mediating Retinal Ganglion Cell Spike Rates Using High-Frequency Electrical Stimulation by Guo, T., Tsai, D., Yang, C. Y., Al Abed, A., Twyford, P., Fried, S. I., et al. (2019). Front. Neurosci. 13:413. doi: 10.3389/fnins.2019.00413

Due to a production error, the captions within Figure 6C artwork have been incorrectly labeled as "blue $(32 \mathrm{mV})$, red $(42 \mathrm{mV})$, and orange $(52 \mathrm{mV})$ " from top to bottom, instead of "orange $(32 \mathrm{mV})$, red $(42 \mathrm{mV})$, and blue $(52 \mathrm{mV})$ ". The corrected Figure 6 appears below.

The publisher apologizes for this mistake. The original article has been updated.

Copyright () 2019 Frontiers Production Office. This is an open-access article distributed under the terms of the Creative Commons Attribution License (CC BY). The use, distribution or reproduction in other forums is permitted, provided the original author(s) and the copyright owner(s) are credited and that the original publication in this journal is cited, in accordance with accepted academic practice. No use, distribution or reproduction is permitted which does not comply with these terms. 


\section{Model}

A

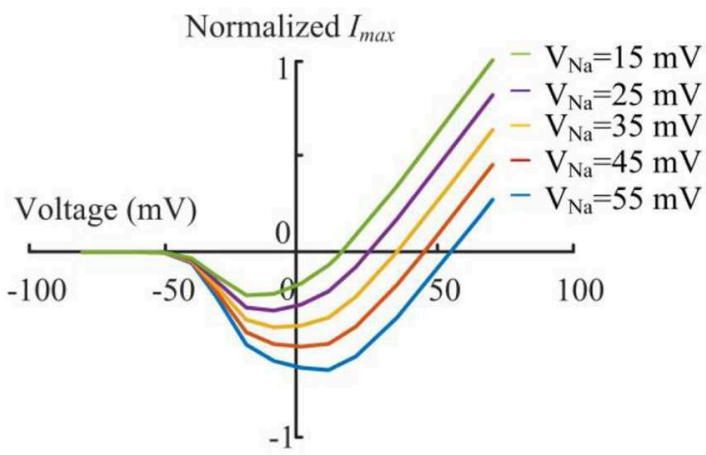

\section{In vitro}

C
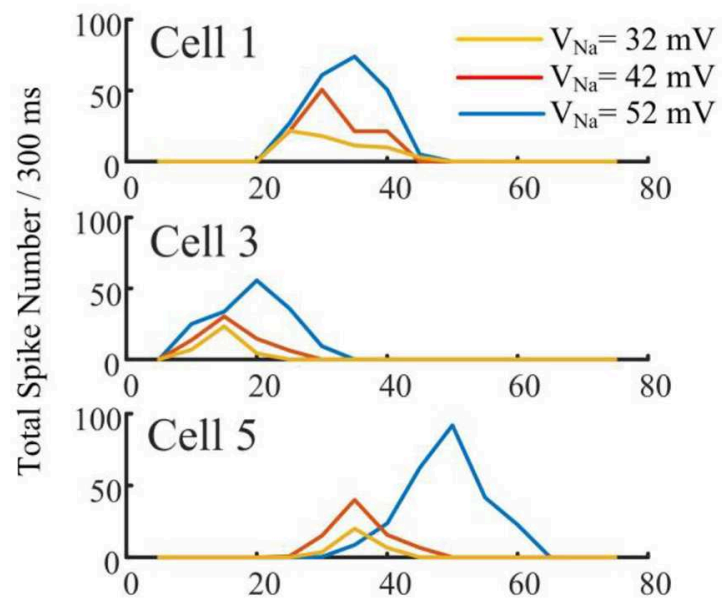

B
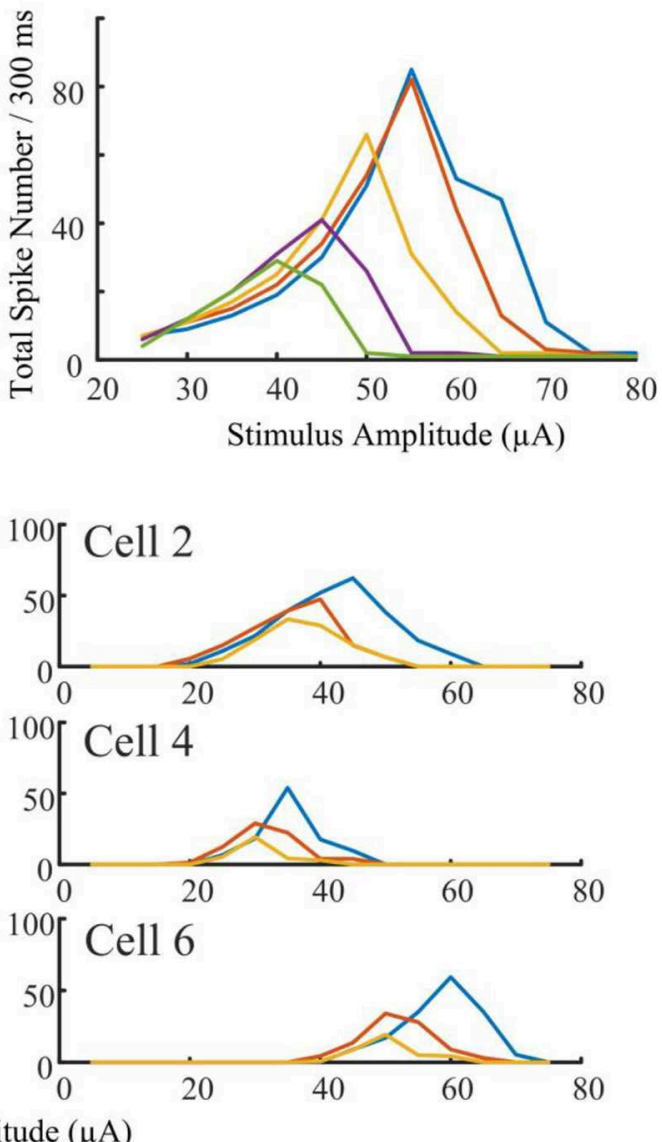

FIGURE 6 | Sodium reversal potentials alter the strength-dependent response. (A) Normalized I-V relationship of the model RGC sodium current for various reversal potentials $\left(V_{N a}\right)$. Shifting $V_{N a}$ to a more positive value delays the reversal of the sodium current. (B) The modeled stimulus-response profile for various $V_{N a}$ values. Shifting $V_{\mathrm{Na}}$ to a more positive value increases RGC excitability during HFS, postponing the suppressive effect, and vice versa. (C) In vitro results of HFS response curves with different $V_{N a}$ values $(N=6)$. The experimentally recorded $R G C$ responses in mouse RGCs generally agree with the simulation results shown in panel $B$, with respect to the changes in amplitude and width of the response curve. (D1,D2) Comparison of model-prediction (red) and experimental data (black) in response to different $\mathrm{Na}^{+}$solutions. Model predictions and in vitro data exhibited similar normalized trends of the total elicited spike number during all pulse trains (D1), and the normalized onset of the falling phase in the spike-stimulus curve in which the total spike numbers saturated or declined (D2). Examples of total elicited spike number and onset was provided in subplots in D1 and D2, respectively. The error bars indicate standard deviation. 